\title{
Theoretical analysis of the study of the phenomenon of bilingualism
}

\section{Gulnoza PULATOVA ${ }^{1}$ \\ Ferghana State University}

\begin{tabular}{l} 
ARTICLE INFO \\
\hline Article history: \\
Received May 2021 \\
Received in revised form \\
20 May 2021 \\
Accepted 15 June 2021 \\
Available online \\
15 July 2021 \\
\hline
\end{tabular}

\section{Keywords:}

bilingualism,

integrated approach,

bilingualism research,

pupil,

bilinguals,

mental mechanism,

ability,

language,

speech.

\section{ABSTRACT}

The article reveals the scientific and theoretical positions of scientists on the need to study bilingualism comprehensively. The paper analyzes the works of scientists on the main aspects of a comprehensive study of bilingualism. The authors of the article argue about the need to implement a new neuropsychological approach to the study of bilingualism.

2181-1415/C) 2021 in Science LLC.

This is an open access article under the Attribution 4.0 International (CC BY 4.0) license (https://creativecommons.org/licenses/by/4.0/deed.ru)

\section{Икки тиллилик ходисасини ўрганишнинг назарий тахлили}

\author{
Калит суизлар: \\ икки тиллилик, \\ комплекс ёндашув, \\ икки тиллиликни \\ ўрганиш, \\ ўқувчи, \\ икки тиллик, \\ рухий механизм, \\ қобилият, \\ тил, \\ нутқ.
}

\begin{abstract}
АННОТАЦИЯ
Мақолада икки тиллиликни хар томонлама ўрганиш зарурлиги хақида олимларнинг илмий-назарий позициялари очиб берилган. Мақолада икки тиллиликни хар томонлама ўрганишнинг асосий жихатлари бўйича олимларнинг ишлари тахлил қилинган. Мақола муаллифлари икки тиллиликни ўрганишга янги нейро-психологик ёндашувни амалга ошириш зарурлиги хақида бахс юритишган.
\end{abstract}

\footnotetext{
${ }^{1}$ Lecturer, Ferghana State University, Ferghana, Uzbekistan.

E-mail: myuldasheva229@gmail.com.
} 


\section{Теоретический анализ изучения феномена билингвизма}

Ключевые слова:
икки тиллилик,
комплекс ёндашув,
икки тиллиликни
урганиш,
уцувчи,
икки тиллик,
рухий механизм,
қобилият,
тил,
нутқ.

АННОТАЦИЯ

В статье раскрываются научно-теоретические позиции ученых по вопросу о необходимости исследования билингвизма комплексно. В работе проанализированы труды ученых об основных аспектах комплексного исследования билингвизма. Авторы статьи утверждают о необходимости реализации нового - нейропсихологического подхода к исследованию билингвизма.

Bilingualism as a social phenomenon is becoming increasingly important and is becoming an important attribute of modern society. The position of the Council of Europe on the proclamation of multilingualism, multiculturalism, cultural conformity, anthropocentricity as significant principles of education system, determines the actualization of the study of the resource of bilingualism in the development of the bilingual student's personality.

Bilingualism is one of the most complex problems and there is no doubt that it is necessary to study it comprehensively. The need to create an integrated theory of bilingualism is recognized by many scientists and some studies have attempted to implement a comprehensive approach to the problem of bilingualism [2; 5]. According to M.M. Mikhailov [7], this is due to the fact that the object under study (bilingualism) is a complex scientific problem and in its study it is necessary to apply the methods of related and non-adjacent sciences - linguistics, psychology, sociology, ethnography, pedagogy, literary studies, etc. This is recognized by all researchers.

A.E. Karlinsky [5] identifies three aspects of the study of bilingualism: linguistic, sociolinguistic and psycholinguistic; M.M. Mikhailov [7] identified four aspects: linguistic, psychological, socio-political and educational-methodological. E.M. Vereshchagin notes that "the problems of bilingualism can be considered from 6 different points of view, and each time the research subject is allocated quite consistently and each time the study assumes the use of an independent methodology" [2. P. 5]. Bilingualism,according to E.M. Vereshchagina, is the subject of research of the following sciences: 1) psychology, 2) linguistics, 3) sociology, 4) psycholinguistics, 5) sociolinguistics, 6) social psychology. Recently, there has been another promising approach to the study of the patterns of bilingualism - neuropsychological [2].

Already in the early monographic studies of bilingualism, attempts to reflect the complexity of the problem are traced. Thus, W. Weinreich noted that "much greater depth and validity of the study of language contact can be achieved on an interdisciplinary basis", since "language contact can be best understood only in a broad psychological and sociocultural context" [1. P. 26]. In this monograph, the problem has already been posed: how sociocultural and psychological factors influence the nature of the bilingual speech product, in particular, the appearance of interference in the bilingual speech. However, the problem was only identified, but not solved. In fact, the complexity of this study was manifested in the consistent consideration of some issues related to the bilingual society, the bilingual individual and the linguistic problems of the interaction of languages in contact. 
The same kind of complexity - on the basis of juxtaposition - is found in the monograph of E.M. Vereshchagin [2], where the psychological, sociological and linguistic aspects of bilingualism are consistently considered.

In the $60 \mathrm{~s}$ and $80 \mathrm{~s}$ of the twentieth century, the complexity of the study of bilingualism was realized through the development of borderline sciencespsycholinguistics and sociolinguistics, combining a linguistic approach with a psychological or sociological one.

The sociolinguistic approach to the study of bilingualism involves the identification of those social factors that affect the nature of the speech product of bilinguals. Yu.D. Desheriev notes that the purpose of a comprehensive study of bilingualism is a socially differentiated characteristic of bilinguistic material (according to socio-territorial, age, socio-group, educational and professional characteristics) in combination with the identification of linguistic conditions (sources) of interference at all levels of language [4]. Developing this point of view, S.I. Treskova points out that the main principle of measurement in sociolinguistics can be considered the principle of a complex multi-level relationship of multiple linguistic and social variables, used to analyze linguistic variability in synchrony and diachrony, taking into account its manifestation in various types of oral and written forms of speech, in different conditions of interaction of languages, dialects, idiolects.

Much attention in the development of the sociolinguistic approach was paid to the search for adequate research methods. The most common method of data collection is the recording of oral or written speech of bilinguals in combination with questionnaires to obtain sociological information. The selected texts are subjected to linguistic analysis, and the resulting linguistic and sociological data are statistically processed.

Within the framework of the sociolinguistic approach, the problem of measuring the level of language proficiency was also discussed. In the study of mass bilingualism, data from population censuses are most often used for this purpose, and in the study of group bilingualism in the field, survey data are used. The level of language proficiency in this approach is determined by the subjects themselves according to specially developed ordinal scales. However, it is noted that in order to obtain reliable data, self-assessment of the level of language proficiency should be combined with an objective assessment. There is no doubt that this approach is promising, but its implementation is hindered by the theoretical lack of development of the concept of "language proficiency" and the methodological lack of its objective measurement.

The task of comprehensive study of bilingualism and, in particular, the Russian language as a means of interethnic communication of students of national schools is also set within the framework of a new direction - pedagogical sociolinguistics - which is being developed by G.V. Kuzmina and her colleagues [8]. Russian RussianAs defined by G.V. Kuzmina, the subject of pedagogical sociolinguistics is the socio-pedagogical and socio-linguistic factors of mastering the Russian language in the conditions of various types of bilingualism and their influence on the level of Russian language proficiency in students of national schools. Special attention is paid to the environment in which the speech development of children takes place. The task of studying the role of family and school education in the formation of different types of bilingualism in schoolchildren is set. The peculiarity of this direction in comparison with traditional sociolinguistic studies of bilingualism is the focus on the study of the speech development of children in various 
socio-cultural conditions, the identification of not only language, but also text competence of students, a broader account of the factors of speech development (national, age, socioeconomic, cultural, pedagogical, etc.).

According to M.N.Guboglo, the complex nature of bilingualism consists of components of a threefold kind: 1) language, which includes all forms and methods of functional development and interaction of languages; 2) personality presented sociogenesis, biogenic, psychogenic and culturogenesis properties (parameters) of the bearers of bilingualism and 3) speech, including knowledge and use of two languages in different areas and situations of life, and to switch from one language to another[3].

The complexity of ethnosociological research is associated with the need to identify and take into account, as far as possible, all the structural elements and structure-forming connections between the components of bilingualism and the components of nonlinguistic reality [3].

In sociolinguistic and ethnosociological studies, the nature of bilingual speech works is directly related to the effect of various social factors. However, still U. Weinreich pointed out that sociocultural factors can influence interference only through the medium of individual native speakers. Therefore, W. Weinreich believed that "the problem of the bilingual individual as a factor determining the processes of interference should be considered as paramount" [1. P. 126]. The same point of view was held by E. Haugen: "The center, the focus of bilingualism - in the brain of the individual. Therefore, the psychological study of a bilingual speaker should take a central place". If the purpose of the study of bilingualism is not just to describe the features of the speech works of bilinguals in comparison with the speech of monolinguals, but to identify the causes of these features, then it is necessary to understand the laws of the process of speech generation and speech perception in bilingualism, and this is a research subject of psycholinguistics. Describing the features of the psycholinguistic approach to the study of bilingualism, A.E. Karlinsky writes: "It is necessary to establish a chain of causal relations that characterize the speech behavior of a bilingual, putting at the end of this chain his speech works, which are the manifestation of deep mental processes" [5. P. 74].

Thus, the form of speech (linguistic problems), the mental mechanism of speech (psychological problems) and the social conditions for the formation and functioning of the mental mechanism (sociological problems) are interrelated in a certain way: "The form of speech is determined by the mental mechanism that has developed in certain social conditions and functions differently in different social situations" [2. P. 5].

So, the most promising approach for the study of bilingualism can be considered a comprehensive approach that allows integrating data from various directions into a single theory. Since the activity is related to the level of speech development of students, bilingualism is one of the factors of the success of an individual's educational activity. Thus, bilingualism is not only socially conditioned, but also socially conditioning phenomenon.

In our opinion, there is a special need for the implementation of a new approach to the study of bilingualism-neuro-psychological, since bilingualism is a process implemented in a deep mental plan, the process of activating intellectual operations (the neurological aspect of the approach), a phenomenon that depends on the individual characteristics of the bilingual (the psychological aspect of the approach), a process that is controlled and manages the training, education and development of students (the pedagogical aspect of the approach). This approach is focused on identifying the deep mechanisms of the formation and development of a bilingual personality, on determining the resource of bilingualism in the development of a bilingual student. 


\section{REFERENCES:}

1. Vaynraykh At. Language contacts: State and research problems / U. Vaynraykh. Kiev: 1979. - P. 263.

2. Vereshchagin E.M. Psikhologicheskaya and methodical characteristic of bilingualism (bilingualism) / E.M. Vereshchagin. - M.: Moscow State University publishing house, 1969. - P. 160.

3. Guboglo M.N. Modern ethnolanguage processes in the USSR: Major factors and tendencies of development of the national-Russian bilingualism / M of N. Guboglo. - M.: Science, 1984. - P. 288.

4. Desheriyev Yu.D. To methodology, the theory of a bilingualism and a technique the bilingualism of researches / Yu.D. Desheriyev // Methods the bilingualism of researches / under the editorship of A.N. Baskakov, V.Yu. Mikhalchenko. - M.: Academy of Sciences of the USSR, 1976. - PP. 6-19.

5. Karlinsky A.E. of a basis of the theory of interaction of languages / A.E. Karlinsky. - Alma-Ata: 1990. - P. 180.

6. Mikhaylov M.M. Bilingualism in the modern world: studies. / M.M. Mikhaylov. Cheboksary, 1988. - $72 \mathrm{p}$.

7. Mikhaylov M.M. Bilingualism: problems, searches... / M.M. Mikhaylov. Cheboksary: Chuvash. book publishing house, 1989. - P. 159.

8. Russian among pupils of schools of federal republics: / G.V. Kuzmin. - M.: Publishing house of NPA of the USSR, 1988. - P. 92. 